\title{
The Impact of the Albanian Folklore of Mitrush Kuteli and De Rada
}

\author{
Dr. Alta Haluci \\ Department of Language and Literature, \\ Faculty of Human Sciences, University "Ismail Qemali", Vlore
}

\begin{abstract}
In his work, Kuteli chose as pretexts the folkloric ballads such as ("Rozafati"), legendary heroic epos ("Gjergj Elez Alia", "Muji and Behuri", "Muji and Zanat", etc.) and the verses of De Rada ("Skanderbeg and Ballaban", "Turku rrëmbeu një arbëreshe -The Turkish grabbed an Arberesh", "The Faith of Costandin"). The presence of some poetry motives from the verses of De Rada in his work "Rhapsody of an Arberesh poem" recreated in "Ancient Albanian Stories" of Mitrush Kuteli is of a special interest not only in the area of text comparison but also in theoretical interest. The issue relates to the trans modeling of the text, concretively with the narration of the poetry. The importance of the recreation of Kuteli is increased from the fact that these works, in contrast to the narrations of J. Kastrati, Dh. S. Shuteriqi, A. Varfi, offered to the young generations of readers a code of communication that overpasses the reading challenges that come from the ancient age of the speech (the case of the verses of De Rada) or its dialect feature (case of northern folk rhapsodies). Kuteli homogenized his work with his authorship (verses) and without authorship (folk ballads). The fact that De Rada had collected the rhapsodies from the folk people themselves, did it play a facilitating role? Can a work of Kuteli be considered an "authorship of second degree" according to the concept of Gerard Genette, a recreational model? These and some other questions will be in the center of this study.
\end{abstract}

Keywords: verses, rhapsody, narration of poetry, recreation model, pretext

\section{Introduction}

In the history of world literature, maybe the foundation that has stood to the time up to today constitutes the most important area of the modern time studies, are the creation in prose, and other types of literature, all developed on the known bases of the folk culture, ballads, and known epos, which today are known as pretexts. Fraj, one of the most known scholars of the theory of modus, in his full paper "Anatomy of the Critics" has offered a wide reference foundation, apart from the holy books and folk culture, on which he thinks stands the largest part of the critical thinking, which explains the literature and its development, by renewing the different schools of study and critical thinking, since the time of Aristotle up to today.

The relation of literature, in its various types, mainly with the folk culture, classified or not, has continued up to the future for the cause of a wide recognition they offer, but also the interesting structures of communication, content rhythm and artistic-esthetic findings.

In the history of Albanian literature, the experience of these relationships that various writers with the passing of time have created this great wealth, in the conditions of a dialogue in new and more complete circumstances, in the case of artistic literature has continued to bring us new approaches in modern prose. Perhaps Dhimiter Pasko (Mitrush Kuteli) will continue to be one of the most fascinating writers and masters of a folk creativity, whether of a rhapsodic spirit or of a ballads, fairy tale or songs of the brave, extended in time and in the genre.

Kuteli's "Ancient Albanian Stories" is one of the most specific works for interpretations being they pre-texts, intertexts textual dialogue and other elements of this relationship that is organized by this structure of communication of artistic literature. Through such an approach, Kuteli not only brought again from another view the communication of early creations, but also continued as a kind of experience the tradition that had been done by the authors of the old Albanian literature, De Rada, Fishta and others. Regarding such a case, I think Kuteli developed a new approach to modern Albanian narrative over these motives.

The direct relations with the motives as pretexts, from the culture and folk memories, kept in forms, means and other methods, form ballads, rhapsodies, songs, folklore, fairy tales, in the Albanian literature appeared in the creations of De 
Rada, but as it has resulted, the author had plenty of objective obstacles, and especially for this reason it seems that Kuteli tries to create communication bridges with the well known renaissance writer, and apart from that, the De Rada model has not failed, even though Konica has kept a harsh opinion, when he states that " De Rada's books are thrown in my closet and are full of dust, as they are written with an archaic language I cannot read..."

Kuteli brought to the attention of the Albanian readers 11 full works, mainly modern Albanian prose, by touching three emblematic historic times; the time when Arbers were dying for unknown powers, the time of the Brave and the war against the ottoman invasion. In these times Kuteli rediscovers the Albanian world through the pretexts "Rozafati", "Faith of Constandin", "Gjegj Elez Alia", "Ymer Age Ulqini", "Muji and the Fairies", "Muji and Behuri”, "Ajkuna cries Omerin", "The young Omeri", "Shega and Vllastari", "The turk grabs an arberesh" and "Skanderbeg and Ballaban", the most known creations, being folk stories, ballads, fairy tales, which all "reason" clearly features, characteristics and an ethopsychological reference of Albanians.

The relationship the author has with this important subject is absolutely clear, and this relationship comes as literature, as a creation and as a model, under the terms of a reinterpretation and dialogue between texts. Regarding Kultel's culture of writing and motivation, the well-known scholar Aurel Plasari has brought us a vertical and horizontal recognition and interpretation of these issues. It is possible that Bodel's approach to modernity as a relationship "... on one hand is instability, circumstance, passerby, flying, half of art, while the other hand is eternal and immutable"1, which find wide ground in such story structures or any other kind.

Regarding this issue, especially when dealing with Kuteli², Plasari sees this kind of writer's relationship as a matter of the "invariant" system, whereby he sees literature as versatility, to coincide with what was slightly marked up, transforming these pre-texts into a modern story. The author writes "And to think of literature as" versatility" means to subjugate this view of all the common elements that you can grasp by recognizing various literatures in time and area, different writers within the same literature and within different literature, but also in the work of a single writer only within it ${ }^{3}$. Only the concept is spread, almost universally acting with the pretexts of the masterpieces of literature. Kuteli, not only constructed a kind of recognition relation with the artistic, and later to the metaphor, and philosophical perception, but also emphasized deeply in these pretexts, he brought for the first time the practice of invariant systems, that the modern literature classifies in four categories; anthropologic, theoretical-ideological, theoretical-literary and linguistic-literary. ${ }^{4}$ The anthropologic invariant is the most functional in the practice of Kuteli, because of the cause of "the world of archetypes" which came through these pretexts, starting from the myths, legends, changed into a universal function, being of the cultural world and the Albanian world, synthesized in the functional symbolic and literal metaphor. This type of Kuteli's relationship we find because of the talent on one hand and the culture that he had obtained in other ways on the other, emphasized from the author Martin Camaj when he writes: "Kuteli comes as a literal and a culture man, as a very complex criticism. As such a man, he does not belong to any literature trend completely, but is a three day friend, wherever he stands within the models" 5

The sources that send to this fundamental report that Kuteli set with the folk creations, as here starts the critical and scholar thinking, are reliable, rationale, as there he felt really good to discover the fantasy, talent and to create wonderful communication structures. In one study organized from Prof. Vehbi Bala, known as "The creation questionnaire"6, Kuteli states that "the real literal foundation was given to me by my mother's fairy tales, our rich folklore I started to know since childhood", and also for the "literal model", he answers "first of all our folklore" and again the folklore: heard fairy tales or the read ones". ${ }^{8}$ As we know, Kuteli had a strong relationship with the folklore with the real meaning of the world. Wherever he went, lived, studied and worked, he worked with folklore such as collecting it and more.

\footnotetext{
${ }^{1}$ Ch.Baudelaiure, "Ouvres completes" Paris 1966, pg 1163,

${ }^{2}$ Aurel Plasari, "Kuteli between the live and dead ", published by"Apolonia", Tirana 1995, pg.20

3 There

${ }^{4}$ A.Marino, "La critique des idees literraires", Bruxelels, 1979, pg.57-80,

${ }^{5}$ M.Camaj:"Kuteli still not known", "Hylli I dritës", 3-4, 1994, pg.82-83,

${ }_{66}$ M.Kuteli, "Answer of the questionnaire of V.Bala", 1962 (manuscript.)

${ }^{7}$ Plasari, cited works, pg.31,

8 There,
} 
This strong relation with the folklore and the folk creations from the rhapsody, ballads, fairy tales and more, not only were interpreted in the best way of the creative and writing process, put everywhere in his social circumstances, but he wonderfully preserved the oral elements, as was the narration by creating a type of illusion, that of confession.

Through a now practice, in which Kuteli put the folk creations, or the subject on which he built such a narrative structure, in a way he differently from the "roman theory"1, the closed epos past was transformed into a open structure of communication, and literal process, but also a necessary content rhythm, even though the time period in the epos or the folk creation of this nature is very gradual, without hurrying the author shows how the hero saddles the horse"2.

Coming into a new reality, being of the relationships, perceptions, critical thinking, esthetical-artistic construction, meaning and metaphor, which necessarily should be together in creation, requires a rational perception for the presented events. It is exactly for this reason, and the condition the pretext stands, by having new conditions, phenomena, supernatural beings, myths, the stories of this nature are consequently narration of perception. Related to such a issue, Plasari brings in memory the term "reluctance in perception" of Torodov, by explaining the causes that the extraordinary events are not happening in a wonderful environment but in another daily contest, so ordinary, ${ }^{3}$ that's why related to such an event Plasar says "As we read again the narrative prose of Kuteli, one of the things we learn from it is that the fantasy and pretextuality is not free ${ }^{4}$.

The use of pretexts, naturally through the known parabole not only in the early literature but also the modern one, brings to attention and with continuous debate many issues and problems of literature in points of view, the form and content, where according to the theory of Janet should be the object of open critics, constitutive elements of works and literal game... the history of esthetical and the technical forms ${ }^{5}$, into a process go the creations of such a nature.

"The Ancient Albanian Stories" Kuteli it is an interesting fact of trans modeling of the texts, the transformation in the structure of communication of this kind and the relation as a strong communication association with the folk ballads, heroic epos and verses of De Rada. Such practices continue to be in the world literature, even in the modern contemporary epos. The issue of deep recognition of this ancient fundamental, apart from creating a plasmatic relation between two approaches, that of pretext and literal text, it brings a new view of the anthropological and ethnographic frame, through a mediation of literature and folk, by making a reciprocal relationship, without losing the first source.

In the contrast to other philologist, folklorists, ethnologists, as it happened to Fishta before him in "Lahuta e Malesise" or Jakov Xoxa or some others, was put as a mediator through the folk subject with the Albanian reader, he gave the reader a modern prose, as a cultural narrator, Barti thinks so for the act of writing: ' to write means ... to own a tangible questioning, which the writer through a ending suspension, decides not to answer. The answer comes from each of us, by bringing the history, speech and its freedom; but as the history, speech and freedom are transformed infinitely, the answer of the world for the writer is infinite; we never stop answering what is written out of each answer; stated, emulated, and then substituted, the meaning goes, the question remains", this does not prevents us to consider the act of writing in the work "The Ancient Albanian Stories" of Kuteli and all the critical thinking and studies about it.

Kuteli naturally gives a number of reasons, such as the relativity of time and space, the temporal conception, the tracing of ancient metathecate, the testimony of a good psychological literature, the significance of the intimate state of affairs, the judgment of Plasar has a suggestion that makes important the interpretation of this creativity as a mix of reality with the subjective world ${ }^{7}$, making it a symbolic, fantastic prose, with a synthesis, magical, but without any magical realism, as has been said in any case.

What can be said with certainty is that in a significant part of his work, Mitrush Kuteli joined the vast culture and deep knowledge of the Albanian world, in the anthropological and ethnographic area, with the master skill of writing. The narrator

\footnotetext{
${ }^{1}$ Mihail Bahtin "Issues of roman", (Epos and roman), pg.35,

2 Viktor Shkollovski, there, "Time convention", pg.199,

${ }^{3}$ Tz.Tedorov "Intruduction a la literature fantastiqua", Paris 1970, pg.41,

${ }^{4}$ Plasari, cited works, pg.49,

5 Zh. Janet, "Figure", "Hejza", Prishtine 1985, pg.80,

${ }^{14}$ R. Barthes, "Mythologies", Tirana 2016, pg.9

${ }_{7}^{7}$ Plasari, cited works, pg.78
} 
in his prose is the merger of two registers into one: there we find the folk narrator and the wise writer. This tradition started with De Rada's rhapsodies and continued as a tradition with the heroic epos created by Fishta with "Lahuta e Malesise"

In the theoretical approach, the evocation of the unwritten folk creations is a typical phenomenon of romanticism, but in Mitrush Kuteli this phenomena does not relate to romanticism, but to an inner creative mission of the author. He put a goal to himself, intentionally, to play the role of a mediator between the creation that traditionally passed from one generation to the other, in the form of folk stories, and now the educated man, who knows how to read and write. In this approach, Kuteli is the first that mediates the folk with literature, a transformation of one to the other. The case of symmetry that we have mentioned between the Rhapsody of a Albanian Poem of De Rada and the Ancient Albanian Stories of Kuteli is much more specific. It is well known that Faik Konica expressed his thoughts about the Poetry of De Rada: His books I have thrown in the closet, as they are written with such an archaic language, as I cannot read. The poor De Rada, if he had gone at least six months in Albania, would have learnt Albanian much better and would have many admirers.

We can imagine what a very limited degree of communication had the verses of De Rada for another reader, when Faik Konica, one of the most talented people of the time, also considered as the most enlightened Euro-Albanian, complained he did not understand.

There was some effort before Kuteli to build communication bridges between De Rada's work and the Albanian reader on the other side of Adriatic. At first it was Luigj Gurakuqi, later there was another effort. It is well known that in the second half of the $20^{\text {th }}$ century De Rada was read in Albanian mostly by adaptations and sometimes even by literary works.

Mitrush Kuteli chose another more productive path. He did not take over the work of the philologist, such as Dhimiter Shuteriqi, Shaban Demiraj and others, but the responsibility of the recreator. If we see closely to this responsibility, we notice something very interesting; any time th elanguage becomes difficult to communicate, Kuteli has interfered with his skills of an educated writer. It is not accidental that his pretexts are from Arberesh ballads and brave eops. In the first case the obstacle came from arcahism, in the second case from dialect. Both were walls that prevented the recognition of these great corpuses of folk heritage. And is exactly Mitrush Kuteli that brings down these walls by transformation of a true literature subject.

This is exactly the difference between the prose of Kuteli and Jakov Xoxa, who relied powerfully on the folk speech, but does not recreate on the bases of folk pretexts and does not play the role of mediator from the unwriten folk materials to the educated reader.

Later on, the tradition of merging the intellectual recognition of the Albanian world with the creative talent as prose writer, similarly to Kuteli, was followed only from Dhimitër S. Shuteriqi.

This happens at a time when Gjergj Pekmezi for example who was part of the friends of society "School of Bukuresht" by republishing the Albanian Bee of Mitko, did the opposite: he took off the Albanian Bee one of the verses of De Rada by referring the principle of subject homogeneity, what is not folklore, should not be part of folk song collection.

In some studies of the recent times, the prose of Kuteli is compared to the magical Latin-American realization, referring the presence of magical, fantastic; the role of folk narration, the transit between the believable realities and unbelievable reality etc..

Except that magical realisation is a phenomenon that featured its characteristics at a time when Kuteli was finished with his writing, it should be recalled that his purpose was not to invent creative methods nor to experiment with folk creativity. His purpose was simply to regenerate some of the monuments of popular heritage that were at risk of being locked in very narrow circles: among the young Italo-Albanians generations and mainly in the Northern Areas of Albania, where the epic rhapsodists continued to astonish foreign researchers. In this sense we can say that Kuteli turned national what was local and threatened to remain an archival phenomenon, uplifted these two legacies from a narrow reading scale to the highest degree of communication; such skill can be recognized as one of the most important merits of his personality. With this we want to say that Kuteli's merit was not only a recreator and a mediator, but also a speech developer and rescuer of communication. 


\section{References}

[1] Ch.Baudelaiure, "Ouvres completes" Paris 1966, pg 1163,

[2] Aurel Plasari, "Kuteli between the live and dead ", published by"Apolonia", Tirana 1995, pg.20

[3] A.Marino, "La critique des idees literraires", Bruxelels, 1979, pg.57-80,

[4] M.Camaj:"Kuteli still not known", "Hylli I dritës", 3-4, 1994, pg.82-83,

[5] M.Kuteli, "Answer of the questionnaire of V.Bala", 1962 (manuscript.)

[6] Mihail Bahtin "Issues of roman", (Epos and roman), pg.35,

[7] Viktor Shkollovski, there, "Time convention", pg.199,

[8] Tz.Tedorov "Intruduction a la literature fantastiqua", Paris 1970, pg.41,

[9] Zh. Janet, "Figure", "Hejza", Prishtine 1985, pg.80,

[10] R. Barthes, "Mythologies", Tirana 2016, pg.9 